\title{
RADAR-OBSERVED SPATIAL AND TEMPORAL RAINFALL VARIABILITY NEAR THE TAPAJÓS-AMAZON CONFLUENCE
}

\author{
JULIA CLARINDA PAIVA COHEN ${ }^{1}$, DAVID ROY FITZJARRALD ${ }^{2}$, FLÁVIO AUGUSTO FARIAS \\ D'OLIVEIRA ${ }^{1}$, IVAN SARAIVA ${ }^{3}$, ILLELSON RAFAEL DA SILVA BARBOSA ${ }^{1}$, ADILSON WAGNER \\ GANDU $^{4}$, PAULO AFONSO KUHN ${ }^{1}$
}

${ }^{1}$ Universidade Federal do Pará, Faculdade de Meteorologia, Belém, Pará, Brasil.

${ }^{2}$ University at Albany, State University of New York, Albany, New York, USA.

${ }^{3}$ Sistema de Proteção da Amazônia, Centro Regional de Manaus, Manaus, Amazonas, Brasil.

${ }^{4}$ Fundação Cearense de Meteorologia e Recursos Hídricos, Fortaleza, Ceará, Brasil.

jcpcohen@ufpa.br,dfitzjarrald@albany.edu, flaviodoliveira@gmail.com, ivansaraiva@gmail.com, i.rafael.ufpa@gmail.com, adwgandu@gmail.com,pkuhn@ufpa.br

Received September 2013 - Accepted July 2014

\begin{abstract}
Standard Amazonian rainfall climatologies rely on stations preferentially located near river margins. River breeze circulations that tend to suppress afternoon rainfall near the river and enhance it inland are not typically considered when reporting results. Previous studies found surprising nocturnal rainfall maxima near the rivers in some locations. We examine spatial and temporal rainfall variability in the Santarém region of the Tapajós-Amazon confluence, seeking to describe the importance of breeze effects on afternoon precipitation and defining the areal extent of nocturnal rainfall maxima. We used three years of mean S band radar reflectivity from Santarém airport with a Z-R relationship appropriate for tropical convective conditions. These data were complemented by TRMM satellite rainfall estimates. Nocturnal rainfall was enhanced along the Amazon River, consistent with the hypothesis that these are associated with the passage of instability lines, perhaps enhanced by local channeling and by land breeze convergence. In the daytime, two rainfall bands appear in mean results, along the east bank of the Tapajós River and to the south of the Amazon River, respectively.
\end{abstract}

Keywords : Precipitation, River Breeze, Instability Lines.

RESUMO: VARIABILIDADE ESPACIAL E TEMPORAL DA PRECIPITAÇÃO OBSERVADA COM O RADAR NA CONFLUENCIA DO TAPAJÓS E AMAZONAS Na Amazônia as series climatológicas estão baseadas na rede de estações meteorológicas de superfície que estão instaladas preferencialmente nas margens de rios. Portanto, o efeito de brisas fluviais que promovem precipitação no interior do continente não está sendo contabilizado nas medidas realizadas nestas estações. Além disto, estudos anteriores encontraram máximo de precipitação no período noturno sobre rios. Assim, este artigo examina a variabilidade espacial e temporal da precipitação na região de confluência dos rios Tapajós e Amazonas em Santarém, visando descrever a importância da brisa fluvial na distribuição da precipitação durante a tarde e definir a extensão da área onde ocorre maxima precipitação no período noturno. A refletividade medida pelo radar meteorológico banda S, instalado em Santarém para um período de três anos foi utilizada, tendo estes dados sido calibrados através dos dados do sensor de precipitação instalado abordo do satélite TRMM. A intensidade de precipitação foi estimada utilizando a relação ZR para o caso convectivo tropical. No período noturno, a máxima precipitação foi encontrada ao longo do rio Amazonas, consistente com a hipótese de que esta precipitação estaria associada a passagem das linhas de instabilidade neste período, talvez esta precipitação também esteja sendo reforçada pela canalização do rio e pela confluência do vento de retorno da brisa fluvial durante a noite. Para o período diurno, observou-se duas bandas de precipitações localizadas no interior do continente, uma ao longo da margem leste e outra ao sul dos rios Tapajós e Amazonas, respectivamente. Palavras-chave: Precipitação, Brisa Fluvial, Linhas de Instabilidade. 


\section{INTRODUCTION}

In the Amazon Basin in situ climate data comes from a sparse network of automatic and conventional weather stations selectively located near communities sustained by river transport. These rivers are tens of kilometers wide, and support common river breeze circulations (Oliveira and Fitzjarrald, 1993, 1994; Silva Dias et al. 2004). Daytime subsidence over the rivers suppresses cloudiness and introduces strong precipitation gradients that can compromise the representativeness of the station data. At synoptic scales satellite-based rainfall observed spatial rainfall variation Clarke et al. (2011) inferred strong breeze effects, but they did not examine diurnal variability. With the recent installation of the SIPAM (Amazon Protection System) rain radar network in the Amazon region one can now observe regional and temporal rainfall patterns and identify the influence of local circulations in greater detail.

Fitzjarrald et al. (2008) analyzed data obtained from a network with automatic weather stations deployed during the LBA-ECO Project (http://www.lbaeco.org) near the confluence of the Tapajós and Amazon Rivers near Santarém, Pará, Brazil. They found an interesting difference in the diurnal rainfall pattern as one goes inland from the rivers. Near the rivers average rainfall was primarily nocturnal, hypothesized to be the result of passing instability lines that propagate into the Amazon Basin from the coast. Afternoon rainfall of local convective origin, suppressed near the rivers, is important inland.

Mean annual precipitation in the Amazon Basin is approximately $2300 \mathrm{~mm} / \mathrm{yr}$, with areas with more than $3000 \mathrm{~mm} /$ $\mathrm{yr}$ in the west, northeast and along the northern coast (Figueroa and Nobre, 1990). Between these maxima is a band of reduced precipitation of about $1600 \mathrm{~mm} / \mathrm{yr}$ exhibiting appreciable spatial rainfall variability.

Very large-scale atmospheric systems also affect the rainfall distribution in Amazonia: 1) the Intertropical Convergence Zone (ITCZ), whose latitudinal oscillations defines the dry and wet seasons; 2) El Niño/Southern Oscillation (ENSO) events; and 3) the South Atlantic Convergence Zone (SACZ), which develops during southern hemisphere spring as a consequence of convection related to the repeated arrival of frontal systems (Marengo et al, 1997).

In the eastern Basin rainfall variability also reflects the type of convective system responsible for the precipitation. Large instability lines (LI) that form near the Atlantic Coast of the Amazon initiated by the sea breeze are known to produce significant rainfall in the Amazon (Kousky, 1980; Kousky et al., 2006). The LI form in late afternoon and propagate into the continent at about $12 \mathrm{~m} \mathrm{~s}^{-1}$ (Cohen et al. 1995), at times propagating as far as $2000 \mathrm{~km}$ into the Basin (Cohen et al, $1995)$. They reach the longitude of Santarém $\left(\approx 55^{\circ} \mathrm{W}\right)$ in the night. The LI can be clearly identified in GOES images and in the CMORPH data product (Kousky et al, 2006). Greco et al. (1990) found that instability line that reached Manaus during ABLE-2B were responsible for $40 \%$ of directly observed rainfall. The somewhat reduced nocturnal convective activity still brings appreciable rainfall to the region (Cutrim et al, 2000; Angelis et al., 2004, Kousky et al, 2006). We take advantage of the natural temporal partition of rainfall types: local rainfall falls in the afternoon, with primarily instability line stimulated rainfall at night.

Silva Dias et al. (2004) studied winds near the AmazonTapajós confluence, with emphasis on data obtained during an intensive field campaign conducted during the 2001 dry season. During the period 24-31 July 2001, they observed and modeled a period of weakened trade wind easterlies associated with the entry of a cold front in the southwestern Amazon Basin (e.g., Marengo et al. 1997). The weakened Basin-scale low-level pressure gradient allowed regional river breezes to dominate. Fitzjarrald et al. (2008) noted that the surface winds near the Tapajós River reverse on days with weak easterlies, changing from the normal easterly and become westerly with the arrival of a river breeze front. A returning land breeze was observed on such days both for the Amazon and Tapajós river breezes.

In summary, while large scale factors explain overall climatic characteristics of the Amazon Basin fairly well, when the focus shifts to smaller regions, one must consider the role of regional landscape features on rainfall. In this paper we use precipitation data estimated using the Santarém meteorological radar to clarify the importance of river breezes and the early morning passage of instability lines on spatial distribution of rainfall near the Tapajós-Amazon confluence, extending the efforts of Fitzjarrald et al. (2008) who had only automatic weather stations at the surface.

In Section 2, we describe the procedures used to analyze the S-band meteorological radar data. Section 3 is devoted to the spatial and temporal rainfall distributions inferred from the average radar returns. We discuss the relative important of river breezes and instability lines on regional rainfall. In Section 4 we discuss our primary results and present our conclusions.

\section{DATA AND METHODOLOGY}

S-band radar reflectivity in the form of CAPPI (Constant Altitude Plan Position Indicator) output at $2 \mathrm{~km}$ altitude between January 2009 and December 2011 (Table 1) are the principal data used in this paper. This radar has a $4.2 \mathrm{~m}$ diameter antenna and operates at $10 \mathrm{~cm}$ wavelength and frequency between 2.7 and $3.0 \mathrm{GHz}$. The data were converted from polar to Cartesian coordinates following the methodology proposed by Anagnostou and Krajewsky (1998), Anagnostou and Morales 
(2002), recently introduced for analysis in the SIPAM at Manaus city network (Saraiva, 2010).

Meteorological radars provide important information for short-term forecasts as well as for research. Calibrating the radar properly is essential to obtaining better quantitative precipitation estimates, but the qualitative information about rainfall location can be equally important in mesoscale studies. Technical considerations include compensating for problems in electronic components, characterizing antenna gain and transmitter strength. Radar reflectivity data must be calibrated with known references. In this paper we use as our reference data from the precipitation radar (PR) aboard the TRMM satellite (Kummerow et al., 1998). We corrected systematic reflectivity errors comparing the Santarém ground radar (GR) with the PR (Anagnostou and Morales, 2002).

We estimated average rainfall by considering the vertical structure of precipitating systems, comparing results from the PR and the GR considering a 3-dimensional volume. Comparisons were made using $43 \mathrm{PR}$ orbits between January 2009 and December 2011, each of which occurred within 3 minutes with GR observations. Histograms (Figure 1) indicate that the average reflectivity of the GR ( $\sim 28 \mathrm{dBZ})$ is larger than that registered by the PR ( 22 dBZ). 1596 cases satisfied the criteria recommended by Anagnostou and Morales (2002). Details of the analysis procedure are given in Saraiva (2010).

Radar reflectivity $(Z)$ was converted to rainfall intensity (R) using the Tokay and Short (1996) for tropical convective case: $\mathrm{Z}=139 \mathrm{R}^{1.43}$. We used these data to calculate average annual rainfall for the three years of interest, for the mean rainy season (15 December-14 July) and for the mean dry season (15 July-14 December).

To clarify the distinction between locally forced convective rainfall and that owing to nocturnally passing instability lines, rainfall totals were also obtained for the daytime (12 to $00 \mathrm{UT}$ ) and nocturnal (00 to $12 \mathrm{UT}$ ) periods.

\section{RESULTS}

\subsection{Annual precipitation}

Mean annual 2009-2011 radar-estimated precipitation (Figure 2) $(1200 \mathrm{~mm})$ is less than that reported by Figueroa and Nobre (1990). Note that the radar makes it possible to distinguish details that the coarse surface station network misses. Presence of a rainfall maximum to the west of the Amazon-Tapajós confluence is consistent with the Fitzjarrald et

Table 1 - Number of days with reflectivity data from the Santarém S-band radar 2009-2011.

\begin{tabular}{lllllllllllll}
\hline Year & Jan & Feb & Mar & Apr & May & Jun & Jul & Aug & Sep & Oct & Nov & Dec \\
2009 & 10 & 28 & 31 & 30 & 26 & 27 & 30 & 28 & 29 & 28 & 27 & 29 \\
2010 & 30 & 28 & 30 & 29 & 12 & 0 & 30 & 30 & 28 & 12 & 15 & 28 \\
2011 & 30 & 26 & 31 & 30 & 29 & 27 & 16 & 29 & 28 & 28 & 29 & 29 \\
\hline
\end{tabular}

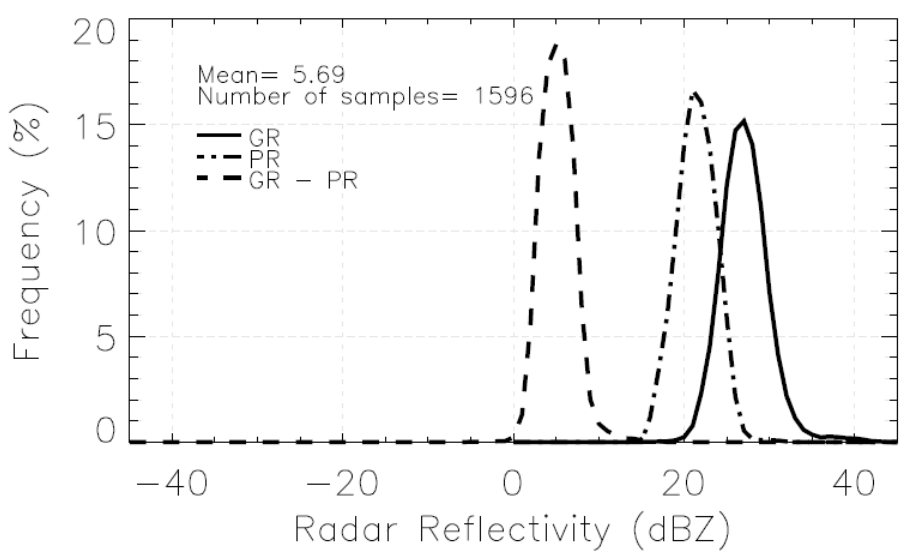

Figure 1- Distribution of reflectivity frequency using the data collected by Ground Radar (GR) and sensor PR (Precipitation Radar) installed onboard of satellite TRMM and the difference between GR and PR. 
al. (2008) findings. A narrow band of enhanced rainfall is also clearly evident along the eastern margins of the Tapajós River, consistent with enhanced cloudiness reported earlier (Silva Dias et al, 2004; Lu et al, 2005). The radar results reveal another, weaker band along the south margins of Amazon River.

A clearer distinction emerges when annual rainfall is split into daytime and nocturnal contributions (Figure 3 ). The
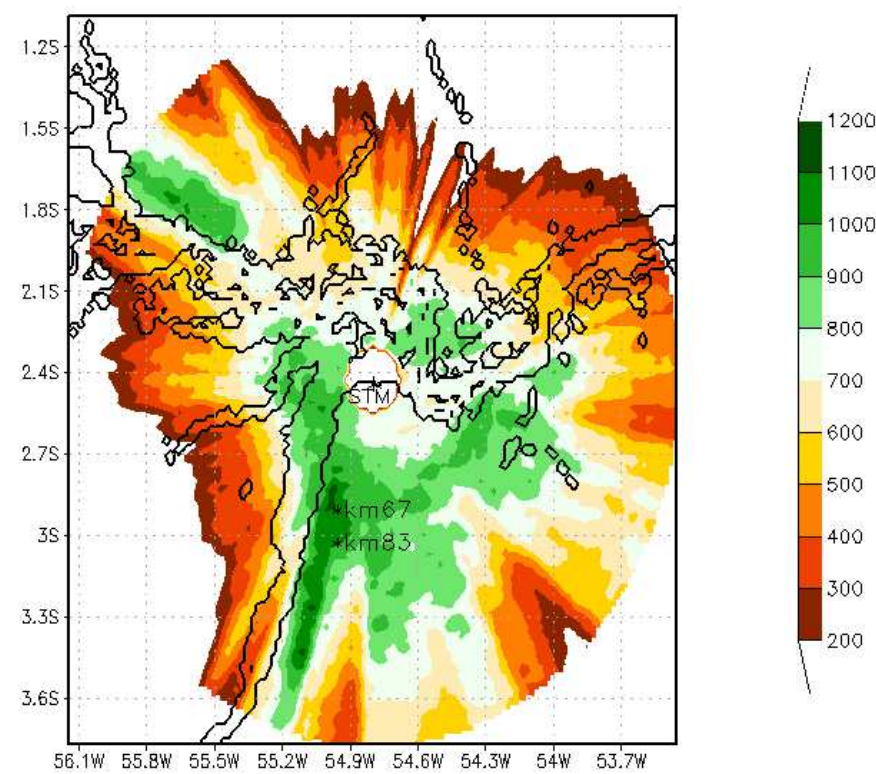

Figure 2 - Mean annual radar estimated precipitation (mm) for 2009 to 2011. The radar site at Santarém airport (STM) and the two LBA flux tower sites ( $\mathrm{km} 67$ and $\mathrm{km} \mathrm{83)}$ are identified.

(a) $00 \mathrm{UT}-12 \mathrm{UT}$

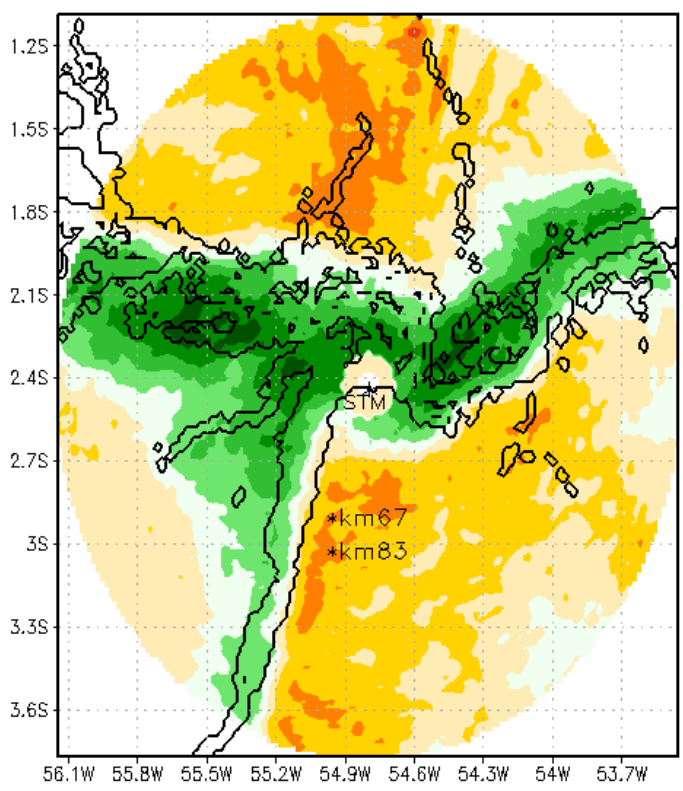

novelty here is that observations delineate clear boundaries that distinguish the influences of the Tapajós and Amazon breezes. Nocturnal rainfall alone dominates close to the Amazon River, while afternoon rainfall maxima are displaced well inland from the main Amazon channel. Cohen et al. (1995) hypothesized that nocturnal rainfall in this region is related to the passage of instability lines. Daytime rainfall has been associated with more locally forced convective activity.

These results confirm and extend earlier work. Fitzjarrald et al. (2008) examined a network of precipitation stations and found that in the Santarém region rainfall maxima occur at 0300 and $1500 \mathrm{UT}$, with a strong preference for only nocturnal rainfall near the river, consistent with the instability line influence hypothesis. With gauge data alone one cannot determine clearly horizontal precipitation boundaries. Considering relatively long-term radar data offers us a more precise way to refine these boundaries.

During daytime the southeast quadrant presents the second largest rainfall percentage, concentrated mainly along the eastern bank of the Tapajós River. North of the Amazon River the rainfall appears preferentially in a region where the terrain exceeds $350 \mathrm{~m}$ (see Figure 6; Fitzjarrald et al, 2008) and could reasonably be associated with orographic uplift.

\subsection{Wet season precipitation}

Despite seasonal changes in total rainfall, the diurnal rainfall distributions are similar. The pattern of average radar-

\section{(b) 12 UT - 00 UT}

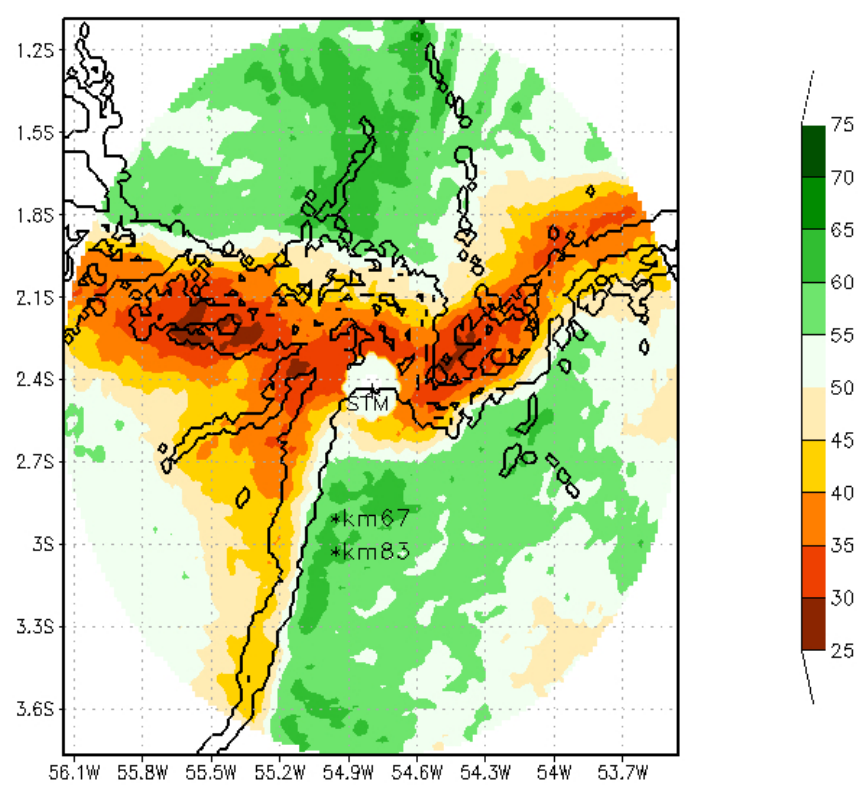

Figure 3 - Percentage of average annual rainfall 2009-2011: a) 00-12 UT; b) 12UT-00 UT. The radar site at Santarém airport (STM) and the two LBA flux tower sites (km67 and km83) are identified. 
based wet season precipitation (Figure 4) dominates the annual signal (Figure 2). The nocturnal rainfall maximum near the rivers' confluence is much larger than the daytime rainfall maximum in the southeast quadrant of the study area (Figure 5).

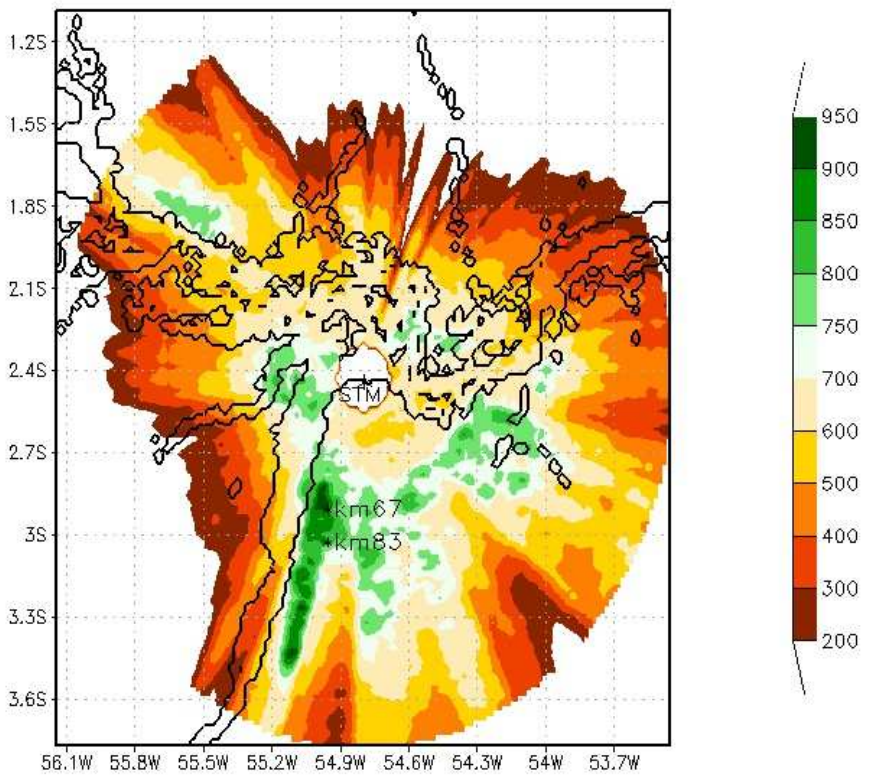

Figure 4 - Mean precipitation (mm) during the rainy season for 2009 to 2011 period. The radar site at Santarém airport (STM) and the two LBA flux tower sites ( $\mathrm{km} 67$ and $\mathrm{km} \mathrm{83)}$ are identified.

(a) 00 UT - 12 UT

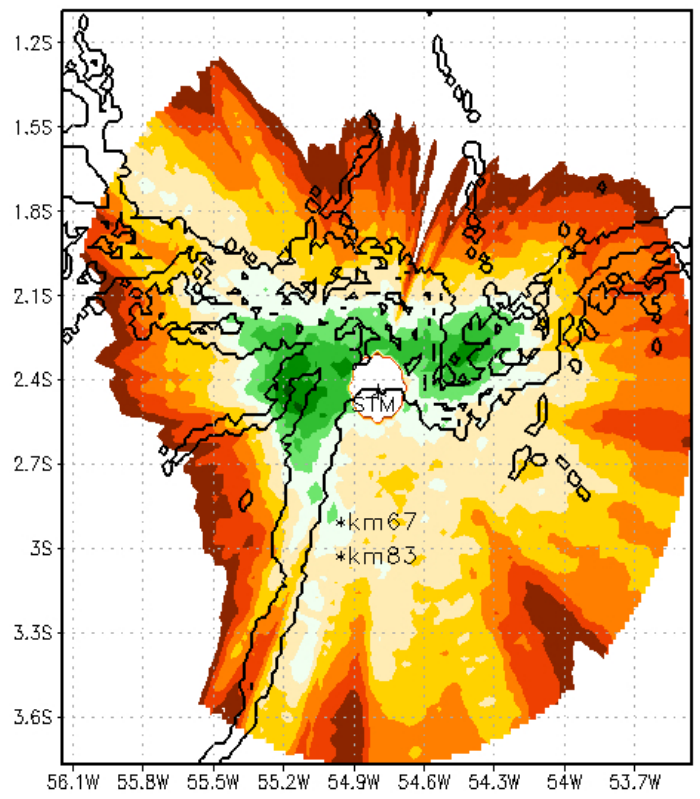

This result is consistent with the hypothesis that the nocturnal rainfall results from deep convection, likely often associated with instability line passage. The daytime maximum is consistent with the idea that the Tapajós river breeze convergence promotes rainfall along the eastern bank, consistent with the cloudiness seen there in selected mesoscale model simulations (Silva Dias et al., 2004 and Lu et al., 2005). Moreover, our results confirm many of the findings from gauge measurements previously reported for the rainy season (Fitzjarrald et al., 2008; Figure 11). The overall rainfall enhancement near the rivers' confluence has not yet been satisfactorily explained. The T-shaped channel at the rivers' confluence could channel a northerly flow down the Tapajós, resulting in a northerly flow along the river converging to the easterly flow above the escarpment, as hypothesized earlier (Lu et al., 2005). Our model studies exploring this issue will appear separately.

\subsection{Dry season rainfall}

The much smaller dry season radar rainfall totals show no marked maximum near the rivers' confluence, but the enhancement along the eastern Tapajós bank is somewhat larger than it counterpart south of the Amazon channel (Figure 6). There is also a rainfall maximum in the northwest quadrant of the study area. Lu et al. (2005) noted the build-up of shallow cumulus along the eastern bank of the Tapajós River and suggested that the $200 \mathrm{~m}$ escarpment there could server as a

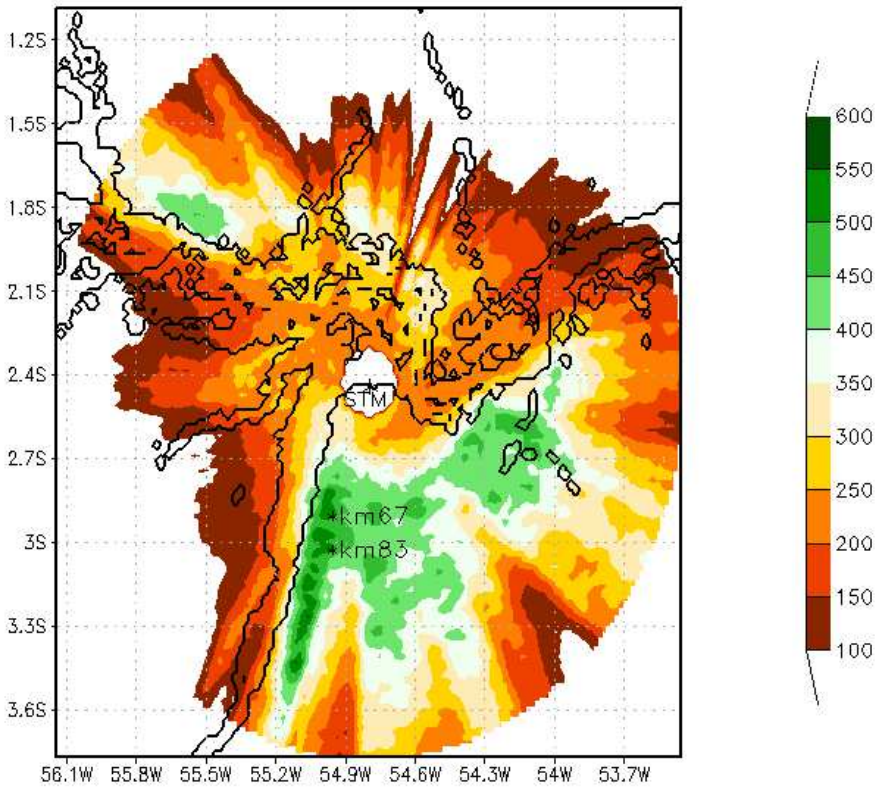

Figure 5 - Mean precipitation (mm) during the rainy season for 2009 to 2011 period: a) 00-12 UT; b) 12UT-00 UT. The radar site at Santarém airport (STM) and the two LBA flux tower sites (km67 and km83) are identified. 
barrier to easterly surface winds, but they offered little insight about precipitation patterns.

\section{CONCLUSIONS}

We examined regional, seasonal and diurnal precipitation variability near the Tapajós-Amazon confluence using the
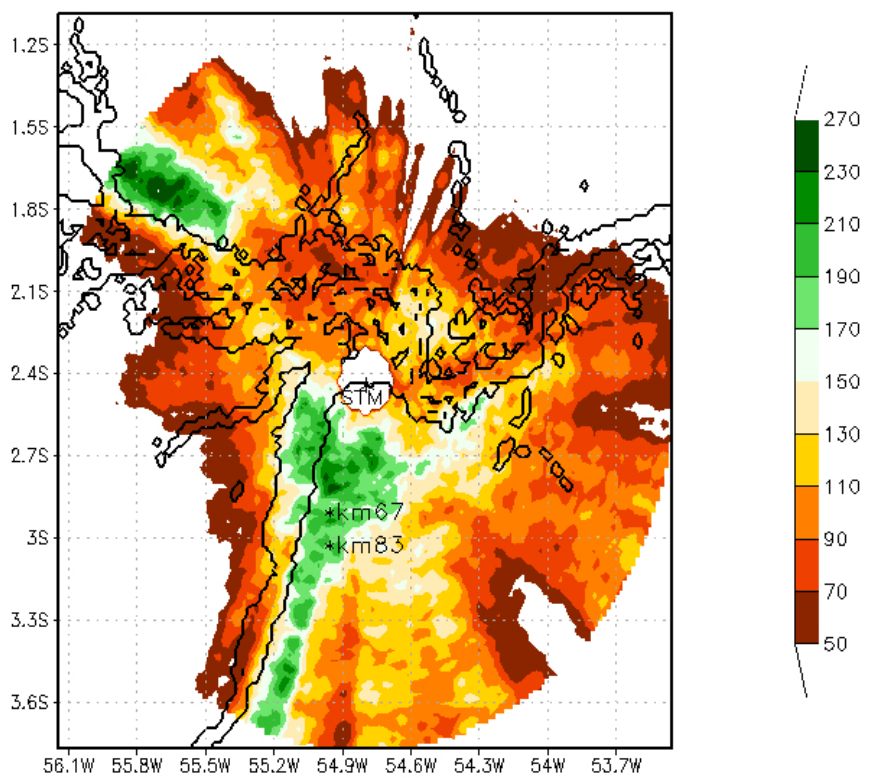

Figure 6 - Mean precipitation ( $\mathrm{mm}$ ) during the dry season for 2009 to 2011 period. The radar site at Santarém airport (STM) and the two LBA flux tower sites (km67 and km83) are identified.

(a) 00 UT - 12 UT

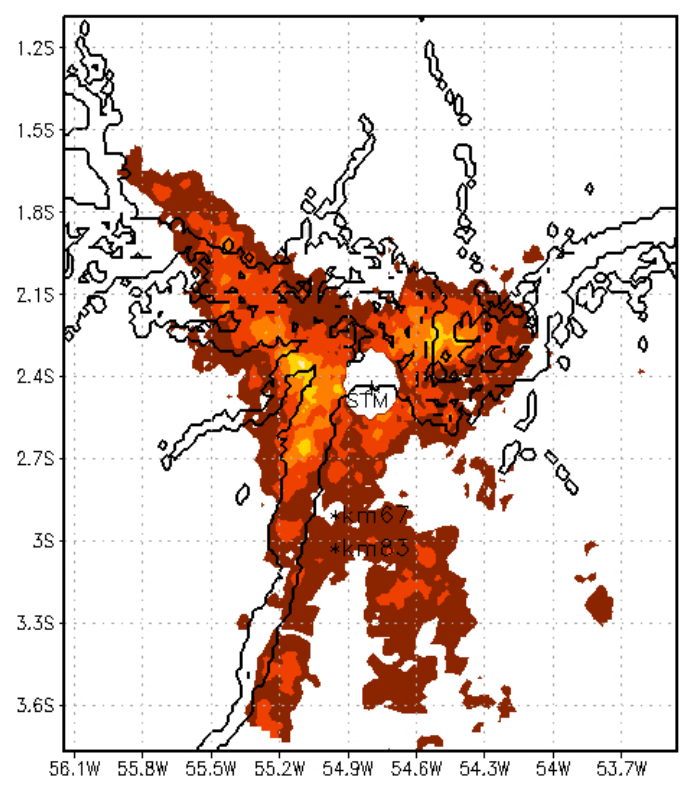

SIPAM S-band meteorological radar at the Santarém airport $\left(\mathrm{STM}, 2.42^{\circ} \mathrm{S}, 54.74^{\circ} \mathrm{W}\right)$. Results clearly establish the geographical extent of the river breeze influences on rainfall. Moreover, averages presented here are consistent with the hypothesis that there is a significant influence of instability lines on nocturnal rainfall patterns. Fitzjarrald et al. (2008) presented the apparently paradoxical result that total rainfall in this region is largest near the Amazon main channel at the same time that strong river breezes in both rivers suppress daytime convection near the channels. The present results are confirm that result, but they identify much more clearly the horizontal extent of each influence.

Just how the passage at night of instability lines lead to amplified rainfall just to the west of the rivers' confluence remains an important research topic for future studies. We note that while the effects noted here may be due to specific regional and local circulations, the preferential distribution of climate stations along the rivers brings any such biases into the longterm record they must be identified and corrected for.

Annual rainfall totals estimated from the radar concur with those reported by Figueroa and Nobre (1990), who used climate data series. However, the radar data alone give a detailed picture of regional rainfall variability that fits well with the scheme that Fitzjarrald et al. (2008) proposed using a small network of surface weather stations.

In the rainy season, nocturnal rainfall is concentrated near to the main Amazon River channel, but daytime rainfall maxima are found inland some $30-50 \mathrm{~km}$. At the longitude

(b) 12 UT - $00 \mathrm{UT}$

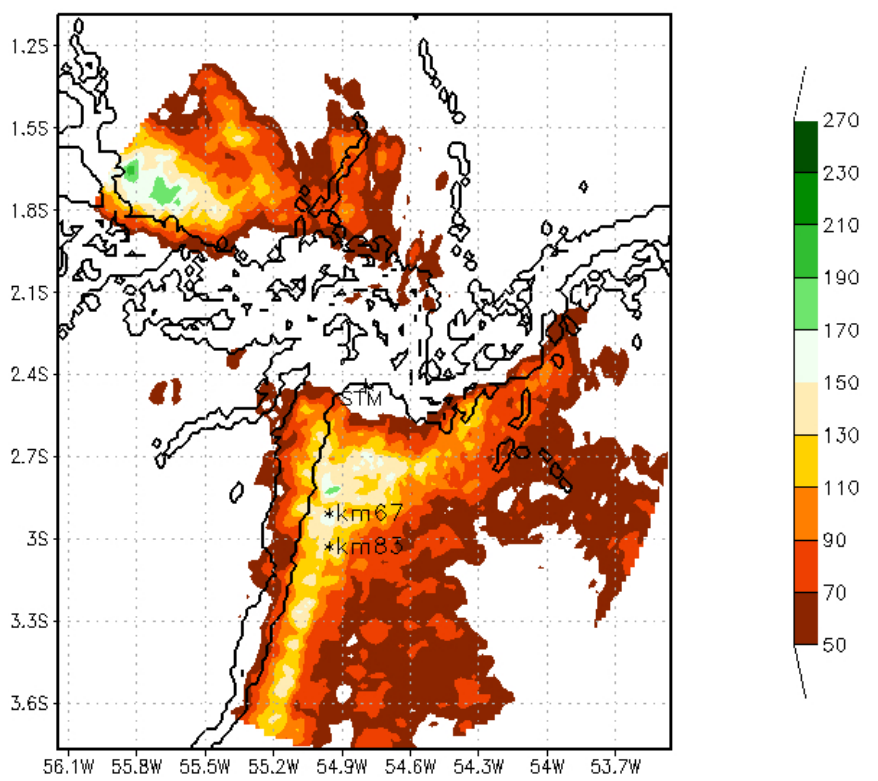

Figure 7 - Mean precipitation (mm) during the dry season for 2009 to 2011 period: a) 00-12 UT; b) 12UT-00 UT. The radar site at Santarém airport (STM) and the two LBA flux tower sites (km67 and km83) are identified. 
of Santarém, nocturnal rainfall is consistent with the passage of instability lines (Cohen et al., 1995), possibly enhanced by channeling effects where the rivers merge. Whether or not the shallow land breeze plays a role in this enhanced convergence warrants further study. A rainfall maximum north of the Amazon river was clearly seen where elevations exceed $350 \mathrm{~m}$. Better resolution of these hypotheses awaits completion of highresolution numerical experiments now in progress.

Dry season rainfall is strongly influenced by river breezes to the south of the Amazon River and to the east of the Tapajós, consistent with cloudiness observed and simulated in the Silva Dias et al. (2004) in one set of case studies and simulated by Lu et al. (2005) in another. Radar observations presented here confirm the principal points raised by Fitzjarrald et al. (2008), that climatological data obtained from riverside stations in the interior of the Amazon Basin must be carefully examined to account for effects of local circulations.

We found that the Tapajos National Forest (FLONATapajós) lies within an interior regime characterized by precipitation likely initiated by local convective activity modulated by the Tapajós river breeze convergence. In both dry and wet seasons rainfall is enhanced in the FLONA compared to its surroundings. Clearly, regional extrapolations or models calibrated with data from the two LBA flux towers in the FLONA (km67, km83; identified in Figures 3-7) must be done accounting for this local mesoscale perturbation. Equal caution extends to those inferring moisture sources from isotopic rainfall analyses (see Angelini et al., 2011).

\section{ACKNOWLEDGMENTS}

This research was supported by CNPq (480071/2009-8) and FINEP (0109057300). The S-band radar reflectivity data was used with permission from SIPAM (Amazon Protection System).

\section{REFERENCES}

ANAGNOSTOU, E.N.; KRAJEWSKY, W. F. Calibration of the WSR-88D Precipitation Processing Subsystem. Weather and Forecasting, v. 13, p. 396-406, 1998.

ANAGnOSTOU, E. N.; MORALES, C. A. Rainfall Estimation from TOGA Radar Observations during LBA Field Campaign. Journal of Geophysical Research, v. 107(D20), p. LBA 35-1-LBA 35-14, 2002.

ANGELIS, C. F.; MCGREGOR, G. R.; KIDD, C. Diurnal cycle of rainfall over the Brazilian Amazon. Climate Research, v. 26, n. 2, p. 139-149, 2004.

ANGElini, I. M., M. GARSTANG, R. E. DAVIS, B. HAYDEN, D. R. FITZJARRALD, D. R. LEGATES,
S. GRECO, S. MACKO, AND V. CONNORS. On the coupling between vegetation and the atmosphere. Theoretical and Applied Climatology, v. 105, n.1-2, p. 243-261, 2011.

ClARKE, T. R.; BUARQUE, D. C.; PAIVA, R. C. D.; COLLISCHONN, W. Issues of spatial correlation arising from the use of TRMM rainfall estimates in the Brazilian Amazon. Water Resources Research, v. 47, n. 5, W05539, 2011.

COHEN, J. C. P.; SIlVA DIAS. M. A. F.; NOBRE, C. A. Environmental Conditions Associated with Amazonian Squall Lines: A Case Study. Monthly Weather Review, v. 123, n. 11, p. 3163-3174, 1995.

CUTRIM, E. M. C.; MARTIN, D. W.; BUTZOW, D. G.; SILVA, I. M.; YULAEVA, E. Pilot analysis of hourly rainfall in central and eastern Amazonia. Journal of climate, v. 13, n. 7, p. 1326-1334, 2000.

FIGUEROA, S. N.; NOBRE, C. A. Precipitation distribution over central and western tropical South America. Climanalise, v. 5, n. 6, p. 36-45, 1990.

FITZJARRALD, D. R.; SAKAI, R. K.; MORAES, O. L. L.; DE OLIVEIRA, R. C. ; ACEVEDO, O. C. ; MATTHEW J, BELDINI, T. Spatial and temporal rainfall variability near the Amazon-Tapajós confluence. Journal of Geophysical Research G: Biogeosciences, v. 114, n. G1, p. G00B11, 2008.

GRECO, G.; SWAP, R.; GARSTANG. M.; ULANSKI S.; SHIPHAM, M.; HARRISS, R.C.; TALBOLT, R.; ANDREAE, M. O.; ARTAXO, P. Rainfall and surface kinematic conditions over central Amazonia during ABLE 2B. Journal of Geophysical Research, v. 95. n. D10, p. 17,011-17,014, 1990

KOUSKY, V. E. Diurnal rainfall variation in northeast Brazil. Monthly Weather Review, v. 108, n. 4, p. 488-498, 1980. KOUSKY, V. E.; JANAWIAK, J. E.; JOYCE, R. J. The diurnal cycle of precipitation over South America based on CMORPH. Proceeding of 8 ICSHMO, Foz do Iguaçu, Brazil, INPE, p. 1113-1116, 2006.

KUMMEROW, C.; BARNES, W.; KOZU, T.; SHINE, J.; SIMPSON, J. The Tropical Rainfall Measuring Mission (TRMM) Sensor Package. Journal of Atmospheric and Oceanic Technology, v. 15, n. 3, p. 809-817, 1998. DOI:10.1175/1520-0426, 1998.

LU, L.; DENNING, A. S.; SILVA DIAS, M. A. F.; SILVA DIAS, P.; LONGO, M.; FREITAS, S. R.; SAATCHI, S. Mesoscale circulations and atmospheric CO 2 variations in the Tapajos Region, Para, Brazil. Journal of Geophysical Research, v. 110(D21), p. D21102, 2005.

MARENGO, J. A.; NOBRE, C. A.; CULF, A. D. Climatic impacts of "friagens" in forested and deforested areas of 
the Amazon Basin. Journal of Applied Meteorology, v. 36, p. 1553-1566, 1997.

OLIVEIRA, A. P.; FITZJARRALD, D. R. The Amazon river breeze and the local boundary layer: I. Observations. Boundary-Layer Meteorology, v. 63, n. 1, p.141-162, 1993.

OLIVEIRA, A. P.; FITZJARRALD. D. R. The Amazon river breeze and the local boundary layer: II. Linear analysis and modelling. Boundary-Layer Meteorology, v. 67, p. 75-96, 1994.

SARAIVA, I. Características dos Sistemas Precipitantes Observados via Radar Meteorológico de Manaus. 2010. 138f. Dissertação (Mestrado em Meteorologia) - Instituto de Astronomia, Geofísica e Ciências Atmosféricas (IAG), Universidade de São Paulo, São Paulo, 2010.
SILVA DIAS, M. A. F.; P. L. SILVA DIAS; M. LONGO; D. R. FITZJARRALD;A. S. DENNING. River breeze circulation in eastern Amazonia: observations and modelling results. Theoretical and Applied Climatology, v. 78, n. 1, p. 111-121, 2004.

TOKAY, A. AND SHORT, D. A. Evidence from Tropical Raindrop Spectra of the Origin of Rain from Stratiform versus Convective Clouds. Journal of Applied Meteorology, v. 35, 355-371, 1996. 